\title{
A Comparative Analysis of the Causes of the Heroine's Tragedy in Tess of the D'Urbervilles and $A$ Rose for Emily
}

\author{
Xiaotong Zhang \\ Zhejiang Ocean University, Zhoushan, China \\ Yihui Li \\ Zhejiang Ocean University, Zhoushan, China
}

\begin{abstract}
From the perspective of feminist theory, this paper absorbs and inherits the existing research results, makes a deep interpretation of the two works, and makes a richer comparison and exploration of the tragic causes of Tess and Emily, which is conducive to a better understanding of the value of the works, revealing the significance of the works, and hoping to provide a new perspective to think for the study of their works and calling on the society to recognize the female subject status and self-identity, then to get rid of the shackles of traditional thoughts and to master the fate of themselves.
\end{abstract}

Index Terms-Tess, Emily, tragic reasons, comparative analysis

\section{INTRODUCTION}

As heroines of well-known masterpieces, predecessors or critics have studied the causes of Tess and Emily's tragedy from different perspectives, such as history, family background and so on, and come to many different conclusions. However, readers are still exploring these two masterpieces and eager to dig more secrets about fate. So the upsurge of solving mysteries seems endless. Secondly, there are many similarities in the causes of Tess's and Emily's tragedies, but it got few attentions. In short, whether there are other reasons for tragedy is still an unsolved problem.

Therefore, this study adopts the literature research method, through reading the relevant literature and books, analyzing and grasping the content of the works. At the same time, through feminist theory and critical thinking, this study will focus on the causes of their tragedies, trying to extract commonness by comparison. Furthermore, some suggestions are put forward for the acquisition of women's happiness.

\section{THE BACKGROUND OF STUDY}

\section{A. Introduction of the Tragedy of Tess}

Tess of the D'Urbervilles, which tells about Tess's difficult and unfortunate life, is generally regarded as Hardy's best novel. Her parents forced her to claim kinship, but she was seduced by Alec, the young master, and even gave birth to a child. Later, she fell in love with Clare, the priest's son, and got engaged. On the night of her wedding, she confessed her past misfortune to her husband, but was abandoned again. A few years later, Tess was entangled by Alec again. At this time, she had to live with her enemy because of her family difficulties. Soon, Clare came back from abroad and expressed regret for his ruthlessness. Tess realized that she had been cheated, thus killed Alec angrily. Finally, after a week of happiness, she was arrested and hanged.

\section{B. Introduction of the Tragedy of Emily}

A Rose for Emily is a famous short story by William Faulkner which took place in a small southern town after the Civil War. Emily was restricted by her father, still unmarried in her thirties, and deprived of the right to pursue happiness. After her father's death, Emily fell in love with Homer, a northerner who came to town to build the railway. When she found out that Homer had no intention of marrying her, she poisoned him with arsenic. From then on, Emily lived a life of isolation in a dilapidated closed house and slept with the dead for 40 years until her death.

\section{Introduction of Feminism}

So far, scholars have not been able to give a unified definition of feminism. This is mainly due to the twists and turns in the process of derivation, development and change of women's thought, which has a wide range of influence, making its content more diversified (Lin, 2018). In addition, feminists based on different backgrounds and positions often have different understanding of the concept of feminism, so it is difficult to make a unified concept of feminism in the world.

Historically, early feminism had two leading ideas, namely, the liberation of women as human beings and the liberation of women ( $\mathrm{Li}, 2005)$. These two leading ideas gradually spread to Britain, other European countries and some 
Latin American countries over time. With the development of this theory, the content is constantly enriched, which emphasizes a higher level of content, which is, calling on people to pursue gender equality and eliminate oppression in political, economic and social life.

For a long time, people regarded Tomas Hardy as a pessimist. There are many mysteries about him and his works. Tess of the D'Urbervilles, as one of his most influential masterpieces, not only aroused people's sympathy for Tess's tragic fate, but also made people explore the causes.

Generally speaking, western researchers always tend to think that Tess is the victim of fate, while domestic commentaries hold the idea that Tess's tragedy is a social one. In recent years, there have been some developments in the study that it is believed that Tess's tragedy is not only a social tragedy, but also the one related to character and destiny. The different emphases on the causes of Tess's tragedy domestically and abroad also make more people study it deeply.

On the other hand, William Faulkner is one of the most influential writers in the history of American literature and his short story "A Rose for Emily" reveals the irreconcilable contradictions and conflicts in the period of social change through the tragic fate of the heroine Emily.

At the same time, there are many scholars who have studied it from different perspectives to analyze the causes of Emily's tragic life. Through various superficial and potential reasons, we can deeply understand the social contradictions of southern American people in various aspects.

\section{COMPARISON OF THE CAUSES OF THE Two TRAGEDIES}

\section{A. Social Environment}

1. The Distorted Social Moral Evaluation System in Victorian England

In the Victorian era, two worlds prevailed all the time: the rich and the poor. The child labor in the slums is extremely poor, while the bourgeoisie is extremely hedonistic and decadent (Wang,2019). Despite her beauty and hard work, Tess, as a laborer and a poor agricultural worker, has a low social status and will naturally be oppressed and humiliated in capitalist society.

Women were limited by men both in society and at home, and the chastity was regarded as the standard to judge whether a woman is pure or not. Even if a woman is defiled and forced to lose her virginity, people will only fight against her, believing that she is evil and cannot be forgiven.

This is precisely to explain the reactionary political system of the bourgeoisie, which shows that the distorted moral evaluation system at that time only cares about the superficiality and ignores the importance of spiritual thought.

2. The Impact of the Disintegration of the Old South on the Aristocracy

After the war, Americans began to move towards the industrial age. In the southern society, the traditional aristocratic forces are shabby but stand still. Although they are declining day by day, they have a deep-rooted sense of racial superiority in their blood and look at groups weaker than their class forces with arrogant eyes (Yuan, 2018). Emily, as a declining aristocrat in the south, was the representative of the traditional southern society at that time.

The townspeople in the novel are immersed in the memory of the glorious past, and they urgently need a traditional incarnation of "idol" to give them spiritual support and comfort. Therefore, the descendant of the town aristocrat, Emily, becomes their eternal monument (Faulkner, 1993).

3. Unfair Social Status of Men and Women

From the perspective of equality between men and women, it is clear that Tess lost her independent status in such a male dominated society. Traditionally, a woman has to obey her husband like a poor slave. The social morality is mainly embodied in the male centered "chastity"(Pan, 2019). Even if the people of that era boldly challenged the old system, one could not give up social morality.

Emily, on the surface, one of the southern women, who represent the traditional virtues of the south, has a very high status. In fact, they are only accessories of the patriarchal society, while the so-called traditional virtues of the South "Lady demeanor" is just the shackles of the patriarchal society to women (Wan, 2018). In this period, women's social status was low and they were bound by traditional ideas, which made them suffer from mental and physical torture.

Although Emily keeps trying to fight for her rights, because of the unfair social system, it finally led to tragedy.

4. Suppression and Indifference of Neighbors and Townspeople

When Tess was seduced, pregnant and giving birth to a child, people discriminated against her and made her escape from her hometown to work as a milkman in a place no one knew her. It is clear that Tess herself is a victim, but people around her are talking about her guilty. The sense of guilt and inferiority makes her dare not face her lover.

As for Emily, the townspeople are advocates and practitioners of the patriarchal system. They always put Emily in a special social position; therefore, as a noble, she must abide by the social requirements for her identity, and cannot freely pursue her own happiness and live the life she wants. They even strongly opposed and tried to destroy Emily's love by various means.

In addition, after seeing Emily buy arsenic from the drugstore, people said that "she's going to commit suicide" which is the best destination for her (Faulkner, 1993). In their opinion, the best outcome they can accept is to bury her with the situation that matched her status as a lady in the south. This destroyed her expectation for happiness, and pushed her into the dark and twisted soul abyss. 


\section{B. Family Oppression}

By the time Tess appeared in the novel, the family was on the verge of collapse. Her father is a foolish and vain peddler, and her mother is vulgar and shallow. The heaviness of the family has cast a shadow on her fate at the beginning. In order to show off their so-called "aristocratic" status and satisfy their vanity, Tess's parents hope to establish a relationship with their relatives. But it was this vanity that thrust Tess into the hands of the wicked. Finally, after her father's death, she had to sacrifice her personality to become Alec's mistress, in exchange for the family's settlement. Being forced to stay with the culprit brought her to the extreme of despair.

In contrast, Emily lost her mother when she was young and her father tried to activate her as a gracious lady who had to obey her father's arrangement. Emily's psychology has been in a state of loneliness and repression for a long time, so that after her father's death, she refused to admit it and not allow others to bury her father. This crazy behavior shows Emily's distorted character and her fear for her father as well as yearning of love.

\section{Love Failures}

\section{Alec's Initial Destruction of Tess}

Alec is a typical playboy. When Tess went to work in the chicken farm, he always looked for opportunities to approach her. Although Tess avoided him everywhere, she was too vulnerable to be against this hypocrite. In the dark, Alec seduced Tess who thus lost the most important thing of a woman in her times, which was an incurable wound in her heart and a heavy burden on her mind. Alec cruelly defiled the naturalization and put Tess on the road of tragedy.

2. Clare's Fatal Blow to Tess

The beginning of love and the end of abandonment destroyed Tess's spirit and soul, and made her go to the edge of life. Clare, an angel in Tess's heart, read widely, believed in science, doubted Christian doctrine, despised hierarchy, wealth and other differences- $-\mathrm{He}$ was an idealized figure in the society at that time.

However, on the night of her wedding, after Tess told him about her past, Clare, who had always been open-minded, fell into deep pain. He was sad, distressed, and suffered from severe mental torture. It can be said that his atrocity destroys Tess's pure heart mercilessly, because his injury to Tess is no less than that of Alec, even more fatal.

3. The Attack on Emily by Homer's Betrayal

As mentioned before, Emily has never been married under her father's control. After father died, she met Homer, the embodiment of new ideas of industrial civilization in the north (Ding, 2010). But Emily's desire for love made her gradually let go and accept new things. Regardless of the difference of status, the criticism of the townspeople and interference from her relatives, Emily went out in a carriage with Homer quiet often.

Emily was completely immersed in the joy of love. However, Homer is "a man who has no intention of becoming a family"(Faulkner, 1993). He will not give up his original life for Emily.

Ironically, she put all her feelings into this love, but didn't get the due return. She was too sad for the variation and breaking of her feelings, and fell into a situation that she couldn't extricate herself, so she chose an extreme way to poison Homer, stayed beside him for more than 40 years, and cut off her contact with the outside world so that she could live proudly in the town as always.

\section{Self Characters}

\section{Tess's Innocence \& Emily's Arrogance}

Just as pure lambs are easily lost and eaten by evil wolves, Tess's purity and goodness are easily destroyed by society's filthy hypocrisy. She lacks more precautions about Alec and when she confessed to Clare about her past, she always has a sense of crime, guilt and inferiority since she lost her chastity.

When it comes to Emily, she actually cherished her noble status. When she went to the drugstore to buy poisons, she ignored the owner's questions and arrogantly showed her dignity and her privilege over the law. This kind of arrogance is also reflected in her treatment of new officials.

On the other hand, she completely closed herself up, lived in isolation, and painfully maintained her most basic dignity. Emily's inability to face up to the changing society bravely further deepens her tragic fate.

2. Tess's Abandoned Resistance \& Emily's Aborted Change

Another characteristic of Tess's character is resistance, but the biggest problem is that her resistance is not complete (Wang, 2019). Although she has enough courage to resist outdated morality and etiquette, she is indecisive. She abides by the rules of the time and always wanders among outdated circles, so she is doomed to become a tragedy. For example, although she despised religion, when her child died, she was afraid that her child would be forced to go to hell, so she secretly baptized her child (Hardy, 2011).

By contrast, after her father's death, Emily gradually realized the decline of the old age, so she made up her mind to change. In appearance, she cut her hair short as if she determined to start her life again; in character, she was no longer timid, and became brave and decisive; in love, she broke away from her father's control and began to pursue the true love she yearned for.

However, she is also a contradictory individual. As mentioned above, she adheres to the old ideas as well as dares to pursue happiness. It's just that she can't get rid of her deep-rooted ideas so she maintained her dignity in an extreme way.

3. Tess's Humility \& Emily's Insanity 
Tess's complete trust and infatuation with Clare shows her idea of male superiority and female inferiority from another aspect. After Clare abandoned her, she was still waiting for and looking forward to him. She had no complaints or struggles about Clare's abandonment. It can be said that it is because of the deep-rooted patriarchy that Tess can not evaluate herself correctly, nor can she establish a healthy relationship with her lover, so she has to fall into the tragic fate of dust.

Emily poisoned Homer and coexisted with his body for a long time, trying to keep her lover forever in this extreme way. She closed herself and guarded the eternal kingdom she imagined. Emily not only stays physically with the God of death, but also pushes herself to the abyss of eternal doom, so that she also dies with him (Ding, 2010).

\section{INSPIRATION TO WOMEN}

\section{A. Keep Up with the New Ideas of the Times}

Emily and Tess, bound by the old ideas, are both impacted by the thoughts of the times. From the ideological point of view, both of them keep the old traditional ideas deeply rooted and cannot keep up with the new ideas in the period of social change. Therefore, it is possible to break through the shackles only by actively seeking women's own happiness and daring to challenge the various ethics formulated by men. They should fully expose the trampling and destruction of human nature by social defects and call for the change of its shortcomings.

\section{B. Set up Correct and Healthy View of Love}

From the perspective of love, Emily and Tess are miserable, because they are all over dependent on their lovers. Tess had full trust in Clare, no complaint or struggle about his heartless abandonment. And Emily used extreme way to poison Homer to stay with him forever. Such a humble and extreme view of love is bound to make women lose their souls and become puppets of men. Therefore, a correct and healthy view of love is essential to the establishment of women's happiness.

\section{Build an Independent and Inclusive Character}

Tess is kind, but she is too pure. She always has a sense of crime and guilt from the inner side. Once she meets such kind of problems, she just swallows her anger and keeps silent. On the contrary, Emily, we can't see the light of human nature in her. Her pride has been deeply rooted-She places herself in the dark corner, and despises anyone. Therefore, how to polish one's own character in the long course of life is also worth thinking about. If Tess can be more determined, Emily can continue to open up the inner world, maybe there will be a different ending.

\section{CONCLUSION}

There are many reasons for the tragedy of Tess and Emily.

First of all, under the historical and cultural background of the patriarchal society at that time, the two heroines were bound by traditional ideas, and the unequal social situation of men and women also made their tragedy more painful. Tess was clearly the victim of the injury, but she was despised and criticized by the people around her, and she was immersed in her own sin. While Emily is regarded as the symbol for she carries the glory and dream of the old South. Therefore, this society does not allow her to do anything without noble status and dignity, and this thought is deeply rooted in Emily's mind.

Secondly, Tess's poor and vain family undoubtedly increased her burden and forced her to give in. And Emily's father, the strict executor of the old order, sowed the seeds for Emily's tragic life.

At the same time, their lovers push them to the abyss. Alec is the first to put Tess in pain, and the heartless abandonment of her beloved Clare is a fatal blow to Tess. On the other side, Homer's betrayal to Emily completely extinguished Emily's hope, which led her to make the most paranoid behavior.

Finally, the two heroines have their own responsibilities. Tess is too pure, too cowardly, too careful on the views of others, and in her heart she thinks she is evil, thus can't bravely pursue her own happiness. While Emily is too lofty to carry out the so-called aristocratic rules to the end, unable to completely change the shackles of the old ideas, limited to the old world.

Even though Tess and Emily are quite different in spirit, they both end up in tragedy, which makes us have to reexamine the fate of women. The terrible patriarchal production may be the root cause, which affects the social atmosphere and people's spiritual level, thus gradually brewing the tragedy of Tess and Emily. We must admit that for women, if the whole society still allows patriarchy to prevail, then women cannot really pursue their love, life and spiritual abundance, thus women's tragedy cannot be avoided. Therefore, every woman must actively participate in the movement of changing society to write a new chapter of her free, noble and transcendent life.

From the perspective of feminist theory, this paper absorbed and inherits the basis of the research results, made a deep interpretation of the two works, and made a richer comparison and exploration of the tragic causes of Tess and Emily, which is conducive to a better revealing of the value and the significance of the works.

In addition, by analyzing the causes of the fate of the two tragic characters, we hope that readers can better understand the spiritual world of people under the specific historical environment, so as to carefully examine women 
and their values. We also do hope that the thesis will still help you in some ways or provide a new thinking perspective for you.

\section{REFERENCES}

[1] Ding Yali. (2010). Tragic Fate, Hopeless Ending -- the Tragic Cause of Emily in Faulkner's Novel the Rose for Emily. Journal of Hebei University of Technology (Social Science Edition), 1,193-195.

[2] Faulkner, W. (1993).Selected short stories of William Faulkner. New York: New York Modern Library.

[3] Hardy, T. (2011).Tess of the d' Urbervilles. Beijing: China International Broadcasting Press.

[4] Lanzen, L. \& Fitzgerald, S. (1988). Short Story Criticism. America: Gale Research Company.

[5] Li Yinhe. (2005). Feminism. Jinan: Shandong people's publishing house.

[6] Lin Shiyi, Zhang Wei. (2018). An Analysis of the Heroines in Rose for Emily and Tess of the D'Urbervilles. Literature Education (1), 5, 48-49.

[7] Pan Honghai. (2019). An analysis of the tragedy of Tess of the d'Urbervilles. Literature education (1), 11, 57.

[8] Pei, Q. (2009).From a Virtuous Maiden to a Vicious Woman-Analyzing the Inevitability of Emily's Tragedy Under Male Power Social Order. Journal of Qiqihar Normal College, 06, $42-44$.

[9] Wan Chunyu, Zhao Yamin, Wan Jiawei. (2018). Emily's Silence and Struggle from the Rose for Emily. Anhui Literature (second half), 11, 58-59.

[10] Wang Qi, Wang Yong. (2017). Interpreting Tess's Tragedy with Psychoanalysis. Forum on Industry and Technology, 16204-205.

[11] Wang Ting. (2019). An Analysis of Tess's Tragedy in Tess of the D'Urbervilles. Overseas English, 12215-217.

[12] Wilfred L.G.(2009). A Handbook of Critical Approaches to Literature. Beijing: Foreign Language Teaching and Research Press.

[13] Yan Tiantian. (2018). Similar Lineage, Different Spirit: A Comparison of Aristocracy between Emily and Tess. China National Expo, 6, 83-85.

[14] Yuan Minmin. (2018). The Decline of the Aristocracy in the South and the Collapse of the Morality of Ladies. Science and education guide (first ten issues), 04150-152.

[15] Zhang, YY. (2016).A Rose Will Never Bloom: Doomed Tragedy of Miss Emily. Advances in Social Science, Education and Humanities Research, 70, 32-35.

[16] Zhang Zong. (2018). The Tragic Inevitability of Tess of the D'Urbervilles under Fatalism. Modern communication, $1,58+57$.

Xiaotong Zhang was born in Jiaxing Province, China in 1998. She is currently a college student in Zhejiang Ocean University, Zhoushan, China. Her research interests include English literature, ancient myths and legends, and English teaching. She has a strong curiosity and passion for exploring the human nature reflected in various literary works

Yihui Li was born in Shandong Province, China in 1982. She received her MA degree from Sichuan International Studies University, China in 2009. She is currently a lecturer in the School of Foreign Languages, Zhejiang Ocean University, Zhoushan, China. Her research interests include western literary criticism and media ecology. 